\title{
Stable ringed seal (Pusa hispida) demography despite significant habitat change in Svalbard, Norway
}

\author{
Magnus Andersen, Kit M. Kovacs \& Christian Lydersen \\ Norwegian Polar Institute, Fram Centre, Tromsø, Norway
}

\begin{abstract}
Ringed seals, which are small phocid seals, range across the circumpolar Arctic, and have evolved in close association with sea ice and depend on it for all aspects of their life history. This research study compares age structure, reproductive parameters, body size and condition during three time periods-1981-82 $(n=277), 2002-04(n=272)$ and 2012-18 $(n=212)$-to study potential changes in demography in ringed seals in western Svalbard, Norway, an area that has undergone dramatic changes in sea-ice conditions during recent decades. Age distributions for the three time periods were similar, with the exception that the most recent period had a higher proportion of young animals. Age at sexual maturity for both sexes was similar for the two most recent periods, both being lower than in the 1980s. Ovulation rates did not vary significantly among the three periods (range 0.86-0.94). Pregnancy rates were only available for the most recent study period $(0.71)$; this value falls within the range reported from other Arctic regions. Body length showed no clear temporal patterns; males were slightly longer in the most recent period, while females were slightly longer in the first period. Data from May in all periods suggest that body condition has not varied significantly through time. In conclusion, although the ringed seal breeding habitat in Svalbard has declined significantly in recent decades, demographic parameters appear to be largely unaffected. Life-history plasticity in combination with a small-scale regional variation in environmental conditions might explain the lack of changes in demography over time.
\end{abstract}

\section{Introduction}

Ringed seals (Pusa hispida) have evolved in close association with Arctic sea ice and depend on it for virtually all aspects of their life history (Smith \& Hammill 1981; Smith et al. 1991; Reeves 1998; Kovacs et al. 2011). This High-Arctic endemic seal begins its life on land-fast sea ice in fjords and along the coastlines of Arctic waters, including those in Svalbard in most areas where land-fast sea ice forms (Lydersen \& Gjertz 1986; Lydersen \& Ryg 1991; Smith \& Lydersen 1991). Some birthing also takes place in areas with drifting sea ice in some parts of the Arctic, including the Barents Sea (Finley et al. 1983; Wiig et al. 1999), although land-fast ice appears to be a strongly favoured habitat for birthing and mating. Ringed seal pups are born in snow caves (birth lairs) that are dug out in snow drifts on the sea ice above a breathing hole (Smith \& Stirling 1975). The birth lair is essential for the survival of pups, which weigh only ca. $4 \mathrm{~kg}$ when they are born; it provides thermal protection and also some protection against polar bears (Ursus maritimus), Arctic foxes (Vulpes lagopus) and other predators (Smith 1980; Gjertz \& Lydersen 1986a; Lydersen \& Smith 1989). Each mother has a series of lairs, and if the lair where her pup is resting is attacked, she will move it to another location (Smith \& Stirling 1975; Lydersen \& Hammill 1993). If there is not enough snow cover by late winter to build such a series of shelters, pup mortality levels are very high. Ice stability is also important because ringed seals have the longest nursing period of any of the northern true seals (members of the family Phocidae) and need stable ice throughout the period of maternal care, which lasts for about six weeks. Warm spring temperatures or rain during the nursing period can result in the collapse of lairs, and hence, reproductive failure (Stirling \& Smith 2004). Ringed seals also use sea ice as a platform for their annual moult in the late spring, when they replace their hair coat and upper skin layers (Carlens et al. 2006). 
Moulting in the water is energetically costly and is much more stressful for the animals than when it occurs on sea ice where they can sunbathe and circulate the blood to the skin in the air (without the high heat loss that occurs in water [Freitas, Kovacs, Ims, Fedak et al. 2008]). Ringed seals also depend on sea ice for resting at other times of year, close to food sources (Freitas, Kovacs, Ims \& Lydersen 2008). They feed predominantly on ice-associated prey, including polar cod (Boreogadus saida), Arctic cod (Arctogadus glacialis) and large Arctic zooplankton species, such as Parathemisto libellula, that are part of the sympagic ecosystem (Gjertz \& Lydersen 1986b; Wathne et al. 2000; Labansen et al. 201 1; Bengtsson et al. 2020).

Ringed seals' extreme affiliation with sea ice raises serious concerns over their future survival in a warming world (Kovacs \& Lydersen 2008). Dramatic reductions in sea ice have already been reported in recent decades in the Arctic, and these declines are predicted to continue, and, in fact, to escalate in the decades to come (Parkinson 2014; Notz \& Stroeve 2016; Overland et al. 2016). Reductions in this unique habitat reflect a direct loss of habitat availability for ringed seals. Climate change will also pose other risks to this Arctic resident: reductions of their traditional lipid-rich prey due to shifts in Arctic food webs stimulated by ice-cover declines and warmer water temperatures; greater risk of disease; more predation by killer whales (Orcinus orca) in some regions; and increased human impacts from shipping, development and pollution in the North (Laidre et al. 2008; Kovacs et al. 2011; Kovacs et al. 2012; CAFF 2013; Laidre et al. 2015; Vanwormer et al. 2019). Declines in pup production, body condition and ovulation rates associated with changing ice conditions have been documented for ringed seals in the Canadian Arctic, where extensive hunt monitoring is undertaken (Reeves 1998; Harwood et al. 2000a, b; Ferguson et al. 2017). A status review of ringed seals led to the listing of this species and bearded seals (Erignathus barbatus) on the US Endangered Species list because a significant portion of their range is expected to be lost in the foreseeable future as a result of sea-ice loss (Gill et al. 2011; Gilg et al. 2012). Similarly, the Committee on the Status of Endangered Wildlife in Canada recommended that the Canadian government list ringed seals as a species at risk under the category "special concern" in their Species at Risk Act. Furthermore, ringed seals have been selected as a key indicator species by Conservation of Arctic Flora and Fauna to assess the status of the Arctic marine ecosystem (Kovacs 2014).

Svalbard is a "hotspot" in the context of climate change. Sea ice has declined markedly in the archipelago over the last three decades, with precipitous changes being observed since 2006 (e.g., Laidre et al. 2015; Muckenhuber et al. 2016), and temperature increases in this region in both the water and the air are well above the norm for the Arctic (Forland et al. 2011; Isaksen et al. 2016). These changes affect the freeze-up and break-up of the land-fast ice, particularly along the west and north coast of Spitsbergen, leading to a shorter sea-ice period and less snow accumulation on top of the ice. Furthermore, modifications to the ecosystem are taking place as Atlantic marine species are moving into the region. The current changes are undoubtedly having an impact on the ringed seal population, but there are few data regarding the effects that these ongoing changes are having on this species in this region in terms of population demography. Ringed seals are difficult to survey, so it is common to evaluate biological parameters measured on hunted animals in order to determine changes in population parameters and to infer population trajectories from such data. Ringed seals are harvested by sport hunters and a few trappers in Svalbard. In the past, some research collections were carried out (Lydersen \& Gjertz 1987; Krafft, Kovacs, Ergon et al. 2006). The current ringed seal harvest in Svalbard is small but biological data collected from locally hunted animals mainly along the west coast, in combination with earlier sampling programmes, provide a time series on demography of the population in the archipelago, which permits exploration of potential changes in vital parameters, growth rates or body conditions in relation to climate change over time.

Given the recent sea-ice habitat degradation for ringed seals in the Barents Sea region, we test the following hypotheses relative to three time periods: (1) recruitment declined because of low pup survival, (2) age at maturity increased because of slower body growth due to reductions in ice-associated prey, (3) reproductive rates decreased (i.e., lower ovulation and pregnancy rates), (4) body sizes decreased because of lower prey availability and (5) body conditions declined.

\section{Materials and methods}

During 1981-82 (Lydersen \& Gjertz 1987) and 2002-04 (Krafft, Kovacs, Ergon et al. 2006), ringed seals were collected during scientific harvests in April-July, while local trappers and sport hunters collected animals in the period 2012-18 during the open hunting season March-October. All sampling was conducted in the fjords on the north and west side of Spitsbergen, Svalbard. The seals were shot on the sea ice in early spring or from small boats in the open-water period in summer and early autumn. When hunting took place in spring, mothers accompanied by pups were avoided. The data from the three periods are still comparable, as the same materials and measurements were collected, and similar field and 
laboratory procedures were followed. The months of sampling varied somewhat in different periods, and some seals were avoided during parts of the sampling; this has been taken into account in the analyses.

For all seals, standard body length and axillary girth were measured to the nearest centimetre using standard methods (Committee on Marine Mammals 1967). Canine teeth from upper or lower jaws were sampled for age determination. From the males, intact pairs of testes were dissected out, and from the females, ovaries and the uterus were collected. The samples were stored frozen at $-20^{\circ} \mathrm{C}$.

\section{Material available}

Two hundred and twelve sets of samples were compiled at the Norwegian Polar Institute from hunter takes during the years 2012-18. Hunting was carried out from Wijdefjorden and Kongsfjorden in the north to Van Mijenfjorden in the south, with most animals being taken in St. Jonsfjorden and Isfjorden (Fig. 1). Some seals were harvested on the sea ice in the late winter and spring (March-June), but most hunting took place during the ice-free season (July-October). Data sets for the periods 1981-82 and 2002-04 comprised data on 277 and 272 individuals, respectively, and the overall sampling area

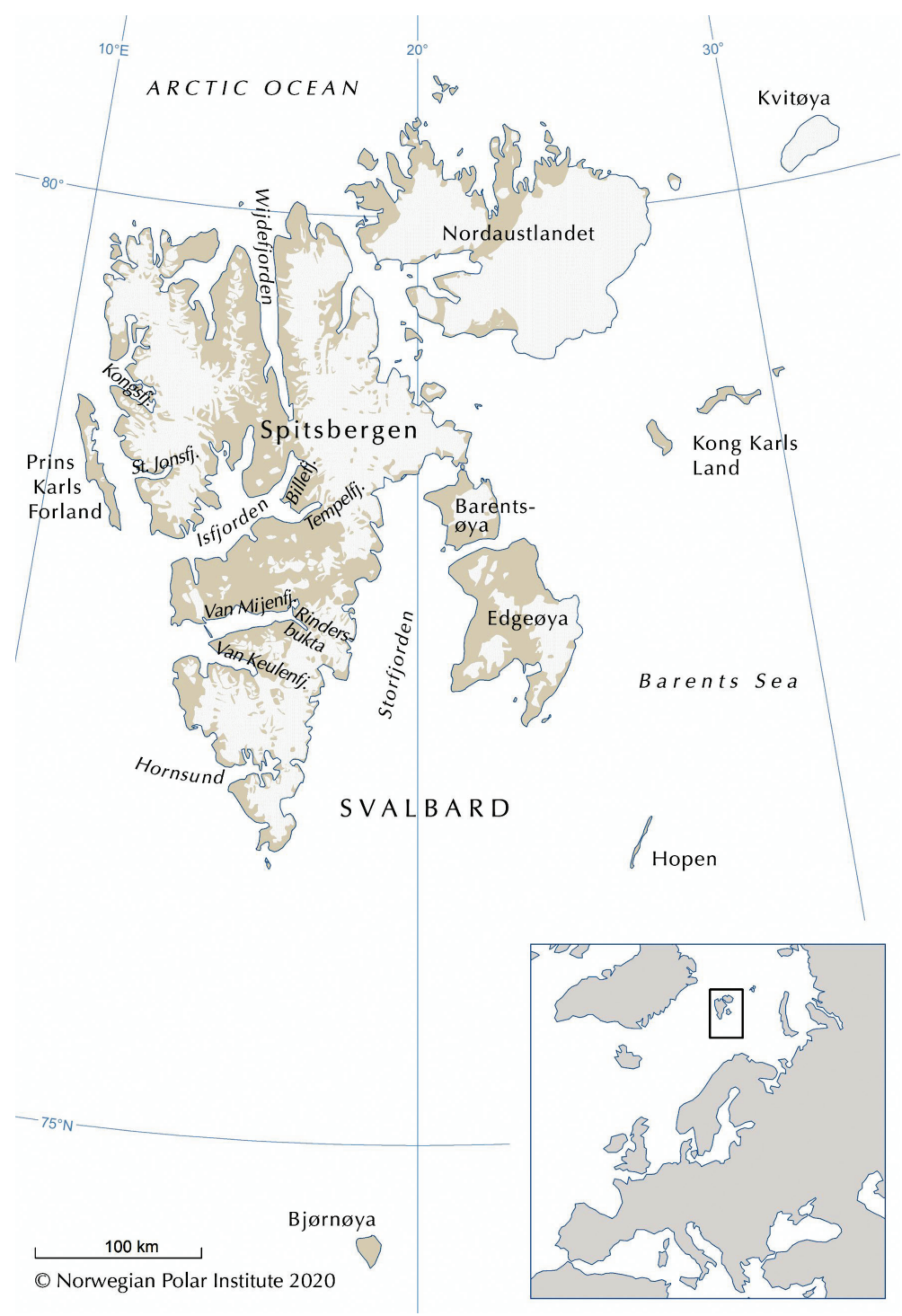

Fig. 1 Map of Svalbard showing the study area and places mentioned in the text (shaded areas represent land; white areas represent glaciers). 
was similar to the 2012-18 harvest but included only the time period April-July (Fig. 1). In all the three periods, some data were lacking for a few seals, so the number of individuals included in the various analyses is variable.

\section{Age determination}

For age determination, jaws were boiled for $30 \mathrm{~min}$ before the canines were extracted. Ages were read from the cementum layer of decalcified, stained longitudinal sections. These details were available for 208 individuals (109 male and 99 females) in 2012-18 (aging conducted by Age Dynamics, Christina Lockyer). Data on age for the periods 1981-82 and 2002-04 were available for 275 (131 male and 144 female) and 272 (170 male and 102 female) individuals, respectively (Lydersen \& Gjertz 1987; Krafft, Kovacs, Ergon et al. 2006).

\section{Reproduction}

Age at sexual maturity was determined from materials collected in 2012-18, and the results were compared with data published for the periods 1981-82 and 200204 . For the most recent data set, indirect evidence of sexual maturity in males were considered using sizes and growth patterns of testes (McLaren \& Smith 1985; Ryg et al. 1991), which were available from 98 known-aged males. Mass of testis, including epididymis, was measured to the nearest $0.1 \mathrm{~g}$ on a laboratory scale (Sartorius BP $210 \mathrm{D})$. When both testes were available from the same individual, a mean value was used. The onset of maturity was considered to occur during an age interval with a sharp increase in testes growth, as confirmed by microscopy for similar samples by Krafft, Kovacs, Ergon et al. (2006), who found all males with testes heavier than $10 \mathrm{~g}$ to be sexually mature. For evaluation of sexual maturity in females, ovaries and uteri were available for most of the animals. Ovaries were sectioned (ca. $5 \mathrm{~mm}$ sections) and examined macroscopically for the presence of follicles: corpora lutea or corpora albicantia. If the ovary contained any of these bodies, the female was classified as sexually mature (McLaren \& Smith 1985). The uterus (when available) was also examined macroscopically, and if it showed signs of earlier pregnancies (i.e., significantly thicker tissue structure), this was also considered as a sign of sexual maturity. Ovulation rates were determined as the proportion of females with a corpus luteum in an ovary per mature female; only samples containing both ovaries were included in the analysis. Pregnancy rates were calculated as the proportion of females with a foetus per mature female in the months August-October, when macroscopic detection of a foetus was possible.

\section{Body growth}

In order to allow comparison with previously published growth studies, body length growth in the ringed seals was described using the von Bertalanffy growth curve (von Bertalanffy 1957; Schnute 1981):

$$
L_{x}=L_{\infty}\left(1-\mathrm{e}^{a\left(x-x_{0}\right)}\right)^{b},
$$

where $\mathrm{L}_{\mathrm{x}}$ is body length, $L_{\infty}$ is the asymptotic value corresponding to adult standard length, $x$ is the age of the animal, $x_{0}$ is an estimated constant for prenatal growth, and $\mathrm{a}$ and $\mathrm{b}$ are constants being fitted to the data by regression, where a determines the rate of approach to the asymptote and $\mathrm{b}$ determines the curvilinearity of this approach (McLaren 1993). The estimated value of $x_{0}$ used here is 0.61, according to McLaren (1993). It represents the time before birth at which the embryo starts growing after the period of delayed implantation. McLaren (1993) stated that when data on length or mass from young age classes, including pups, are scarce, which is true for this study, using the estimated $x_{0}$ value serves to anchor the growth curve at its lower end. Growth functions were fitted using the vbStarts-function in the FSA-package (http://www.rforge.net/FSA) and the nls-function in $\mathrm{R}$ version 4.0.3 (R Core Team 2014). Data on the analysis of age-related length growth were available for $n=275$ in 1981-82 (131 males and 144 females), $n=272$ in 2002-04 (170 males and 102 females) and $n=207$ in 2012-18 (109 males and 98 females). The asymptotic values and the parameter estimates are given with 95\% CIs in the nls-function output. Boxplots (with all data points plotted) are presented to visualize the data for the three sampling periods for both sexes. The effect of sampling period on body length was further tested by linear regression (function $\mathrm{lm}, \mathrm{R}$ version 4.0.3) using data for fully grown individuals ( $\geq 8$ years). Values of $p$ and $F$ are given, model estimates and corresponding CIs (function confint, R) are presented, and statistically significant relationships are denoted.

\section{Body condition}

Variations in body condition by both month and time period were analysed using C-index, an index of body condition based on morphometric measurements (Committee on Marine Mammals 1967):

$$
\text { C-index }=(A G \times 100) \text { SL- } 1,
$$

where AG is axillary girth and SL standard body length. C-index data were available from 132 males and 144 females in 1981-82, 173 males and 103 females in 
2002-04, and 93 males and 92 females in 2012-18. For analyses of between-period trends, only data from March to July were included. Boxplots are presented to visualize the data, and the effect of sampling period on body condition was tested by linear regression (function $\mathrm{lm}$, R version 4.0.13). For 2012-18, data were also available for August, September and October, thus enabling an analysis of seasonal patterns. The effect of month on $\mathrm{C}$-index values was analysed by linear regression (function $\mathrm{lm}, \mathrm{R}$ version 4.0.3), and a boxplot with all data points plotted is given for visualization of the data. For the linear regressions, $p$ values and $F$ values are given, model estimates with corresponding CIs are presented and statistically significant relationships are denoted.

\section{Results}

\section{Age distribution}

During 2012-18, ages of ringed seals in the hunt varied from 0 to 33, with the oldest male being 26 years and the oldest female being 33 years); median age was nine years. The oldest animals during the periods 1981-82 and 2002-04 were 45 and 30 years old, and median ages were 12 and 10 years, respectively. Young animals 0-3 years of age constituted $25.0 \%$ in the $2012-18$ sample. In comparison, 0-3-year olds constituted 13 and 13.5\% of the samples for the periods 1981-82 and 2002-04, respectively (Fig. 2). A slow, decreasing trend in the
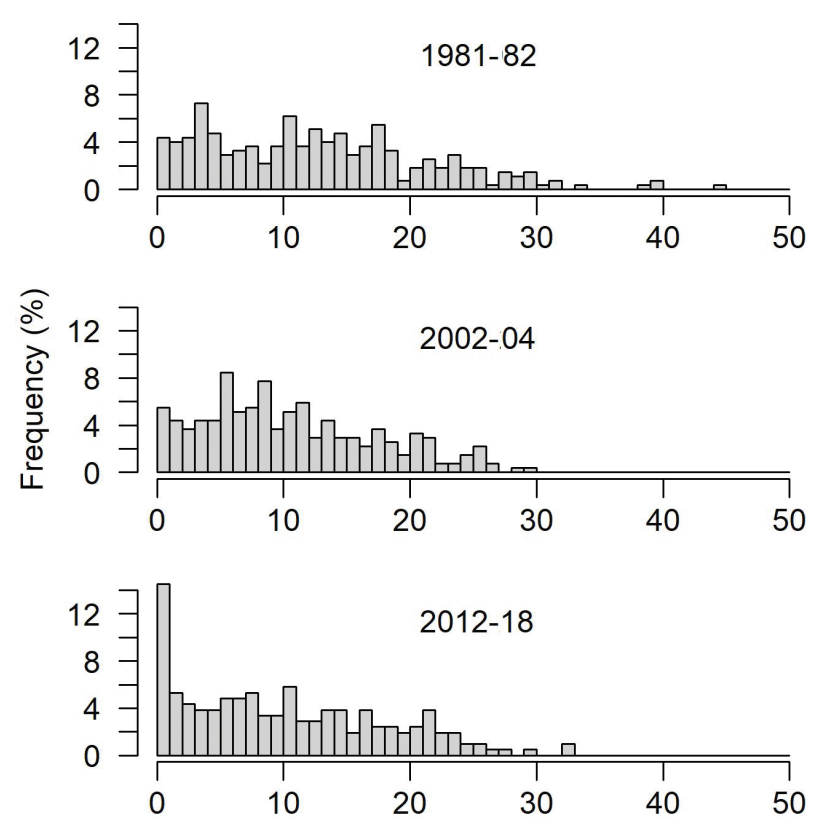

Fig. 2 Frequency of age classes in Svalbard ringed seals sampled in 198182, 2002-04 and 2012-18 (sexes combined). number of animals is observed from the youngest age groups up to 20-25 years, followed by a sharp decline thereafter in all the three periods (Fig. 2).

\section{Reproduction}

The age-related growth pattern of testes during 2012-18 (Fig. 3) was similar to that seen in the period 2002-04 (see Krafft, Kovacs, Ergon et al. 2006), indicating that age at maturity was attained from three to six years for males. Lydersen \& Gjertz (1987) reported age at maturity for males to be between five and eight years during 1981-82 (Table 1). Reproductive organs were available for 100 females for 2012-18, and the maturity status could be determined for 94 of these animals. Age data were available for 92 individuals, of which 74 were mature. In 2012-18, females reached sexual maturity starting at an age of three. Fifty percent of three-year olds were mature, while 100\% of the four-year olds were mature. Similar analyses concluded that females matured between three and six years of age in 1981-82 and between two and four years of age in 2002-04. Determination of the presence or absence of a corpus luteum was possible for 67 mature individuals in 2012-18,63/67 had ovulated, so the ovulation rate $\left(F_{\mathrm{CL}} / F_{\text {mature }}\right)$ was 0.94 . Comparable rates were 0.91 for $1981-82$ and 0.86 for 2002-04. Fifty-two mature female seals were collected from August to October in 2012-18, of which 37 had a foetus. The pregnancy rate was, therefore, 0.71 (Table 1). Ages of the females bearing foetuses ranged from four to 28 years.

\section{Growth}

Von Berthalanffy growth curve parameters revealed quite similar growth patterns between sexes and periods, except for males in 2012-18 being longer than females (Table 2, Fig. 4). Linear regression analyses further showed that the body length of adult animals (at least eight years of age) over the three collection periods differed somewhat for both males $\left(F_{(2,234)}=10.7\right.$, $p<0.05)$ and females $\left(F_{(2,245)}=7.9, p<0.05\right.$; Fig. 5, Table 3), although low $F$ values indicated weak patterns. While males were slightly longer in the most recent sample (2012-18: $134.4 \mathrm{~cm}, \mathrm{CI}=129.4,139.3)$ compared with both the earlier periods (1981-82: $129.1 \mathrm{~cm}$, $\mathrm{CI}=127.2$, 131.0; 2002-04: $127.4 \mathrm{~cm}, \mathrm{CI}=122.9$, 131.9), females were slightly longer in the oldest sample (1981-82: $130.5 \mathrm{~cm}, \mathrm{CI}=128.8,132.2)$ relative to the two more recent data sets (2002-04: $125.5 \mathrm{~cm}$, $\mathrm{CI}=121.2,129.8 ; 2012-18: 126.9 \mathrm{~cm}, \mathrm{CI}=122.5,131.3)$ (Fig. 5, Tables 2, 3). 


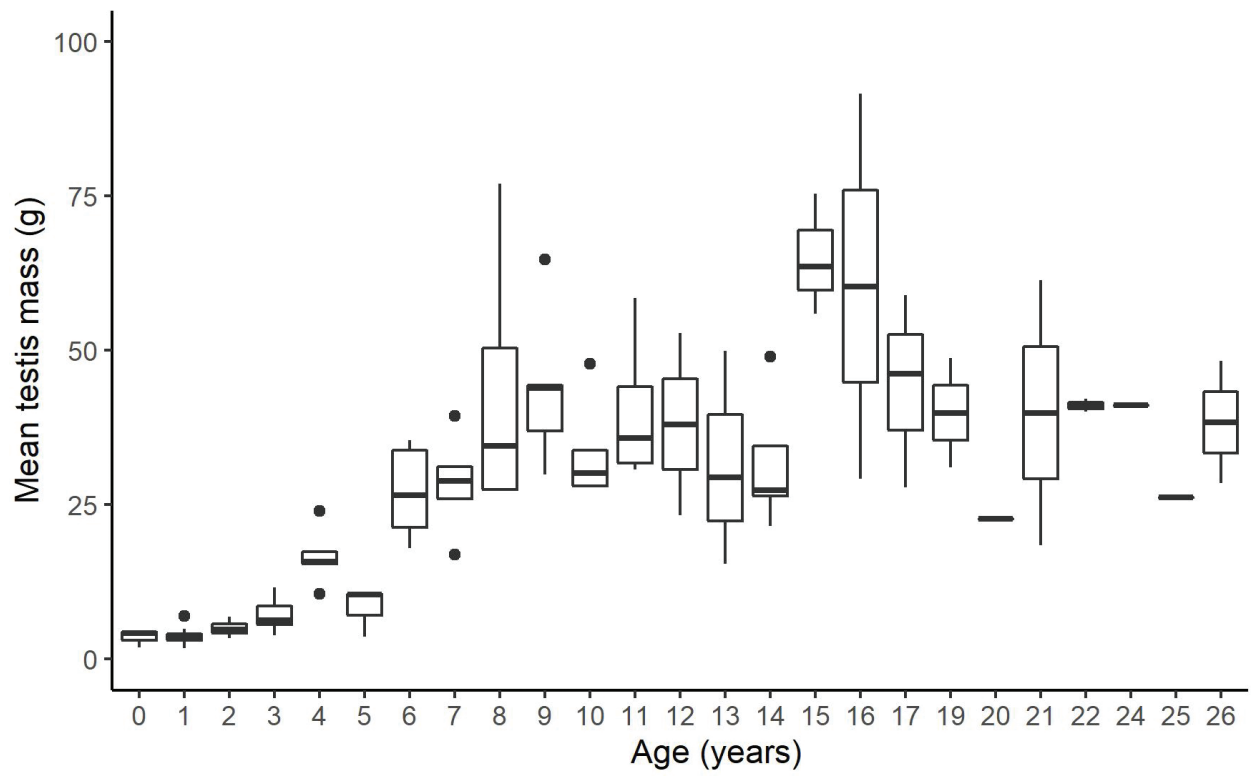

Fig. 3 Testis mass as an indication of the onset of sexual maturity in male ringed seals in Svalbard during 2012-18.

Table 1 Age at sexual maturity in males and females, ovulation and pregancy rates for ringed seals in Svalbard in three time periods.

\begin{tabular}{lcccc}
\hline $\begin{array}{l}\text { Time } \\
\text { period }\end{array}$ & $\begin{array}{c}\text { Male age at } \\
\text { maturity }\end{array}$ & $\begin{array}{c}\text { Female age } \\
\text { at maturity }\end{array}$ & $\begin{array}{c}\text { Ovulation rate } \\
F_{\text {CL }} / F_{\text {mature }}\end{array}$ & $\begin{array}{c}\text { Pregnancy rate } \\
F_{\text {Fetus }} / F_{\text {mature }}\end{array}$ \\
\hline $1981-82$ & $5-8$ & $3-6$ & 0.91 & - \\
$2002-04$ & $3-6$ & $2-4$ & 0.86 & - \\
$2012-18$ & $3-6$ & $3-4$ & 0.94 & $71 \%(37 / 52)$ \\
\hline
\end{tabular}

aSexual maturity of males was assessed by testes size or the presence of sperm cells in the testis. "'Sexual maturity in females was confirmed by follicles, corpora lutea or corpora albicantia, in the ovaries. The uterus was also examined macroscopically for signs of earlier pregnancies.
Table 2 Von Bertalanffy growth function parameter estimates for ringed seal length-age data collected during three periods (1981-82, 2002-04 and 2012-18) in Svalbard. Growth functions were fitted using the vbFuns-function in the FSA package (http://www.rforge.net/FSA/ InstallFSA.R) for $\mathrm{R}$ (R version 4.0.3).

\begin{tabular}{|c|c|c|c|c|}
\hline \multirow[t]{2}{*}{ Growth parameter } & \multirow[t]{2}{*}{$n$} & \multicolumn{3}{|c|}{ Parameter estimates } \\
\hline & & $L_{\infty}$ & $a$ & $b$ \\
\hline Male length, 1981-82 & 131 & $129.39 \pm 1.08$ & $0.44 \pm 0.06$ & $-2.10 \pm 0.46$ \\
\hline Female length, 1981-82 & 144 & $131.35 \pm 1.12$ & $0.27 \pm 0.04$ & $-3.80 \pm 0.79$ \\
\hline Male length, 2002-04 & 170 & $127.42 \pm 0.81$ & $0.49 \pm 0.07$ & $-1.82 \pm 0.51$ \\
\hline Female length, 2002-04 & 102 & $126.30 \pm 1.23$ & $0.29 \pm 0.07$ & $-4.38 \pm 1.50$ \\
\hline Male length, 2012-18 & 109 & $136.75 \pm 1.89$ & $0.24 \pm 0.04$ & $-4.43 \pm 0.76$ \\
\hline Female length, 2012-18 & 98 & $127.77 \pm 1.31$ & $0.29 \pm 0.07$ & $-4.46 \pm 1.28$ \\
\hline
\end{tabular}

\section{6}

\section{Body condition}

Males in 2004-05 had higher C-index values (80.3, $\mathrm{CI}=78.0,82.6)$ compared to those in 1981-82 (76.5, $\mathrm{CI}=75.5,77.5)$ and $2012-18(72.6, \mathrm{CI}=74.5,80.8)$ $\left(F_{(2,337)}=16.04, p<0.05\right)$, but low $F$ values indicated weak patterns. For females, there were no effect of sampling period on C-index (1981-2002: 80.3, CI = 79.1-81.5; 2002-04: 81.3, CI = 78.2, 84.4; 2012-18: 79.6, CI = 75.4, 83.8) $\left(F_{(2,273)}=0.8, p=0.44\right)$ (Fig. 6, Table 4). When considering the data set for the period 2012-18, which includes data from March to October, significant differences in condition were seen seasonally $\left(F_{(7,177)}=6.9\right.$, $p<0.05)$, with $\mathrm{C}$-index values being lowest in June and highest in the autumn (August-October; Fig. 7).

\section{Discussion}

Dramatic environmental changes have been taking place in the marine environment in the Svalbard Archipelago and the broader Barents Sea region (Eriksen \& Dalpadado 2011 ; Buchholz et al. 2012; Fossheim et al. 2015; Laidre et al. 2015; Eriksen et al. 2017; Lind et al. 2018). Sea ice has declined in Svalbard over the last three decades (e.g., Laidre et al. 2015; Muckenhuber et al. 2016), as temperatures in the water and the air have increased in the region (Forland et al. 2011; Isaksen et al. 2016). This has affected the timing of the freeze-up and break-up of the land-fast ice, with shorter sea-ice periods and less snow accumulation on the ice. However, despite the significant 

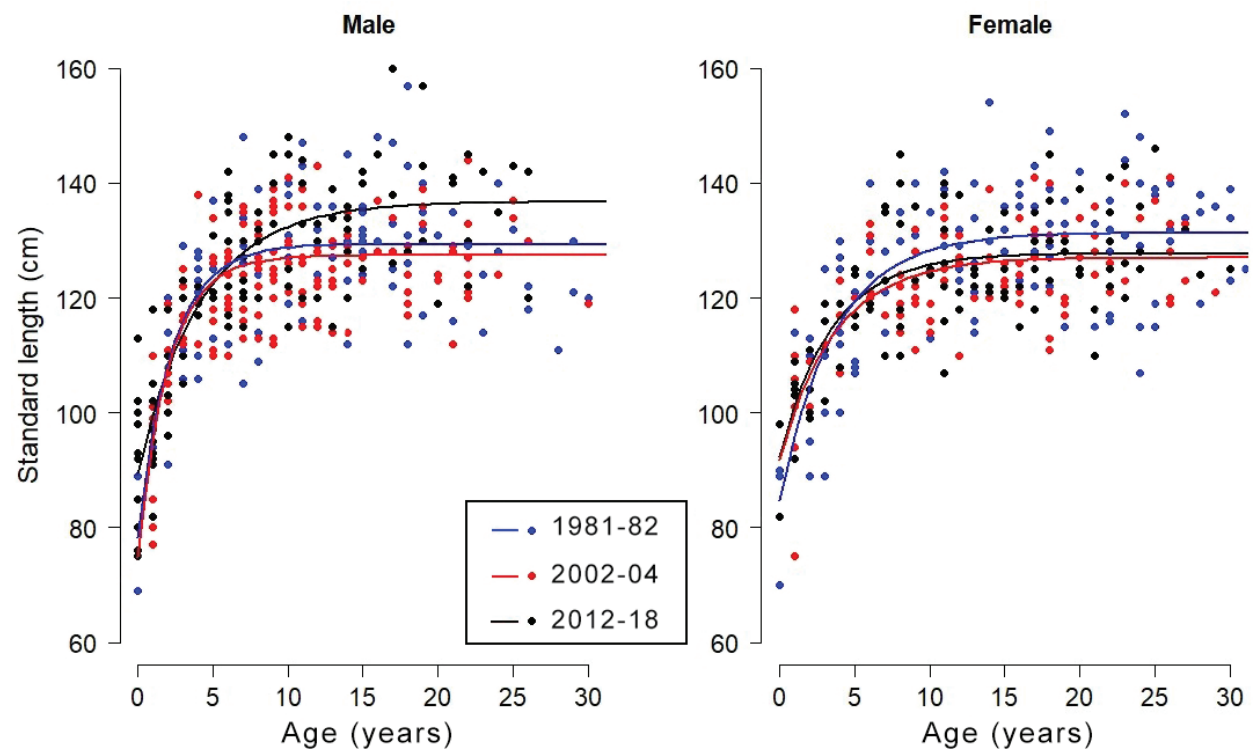

Fig. 4 Von Bertalanffy growth function describing standard length versus age (truncated at 30 years) for male and female ringed seals sampled in Svalbard during 1981-82, 2002-04 and 2012-18.
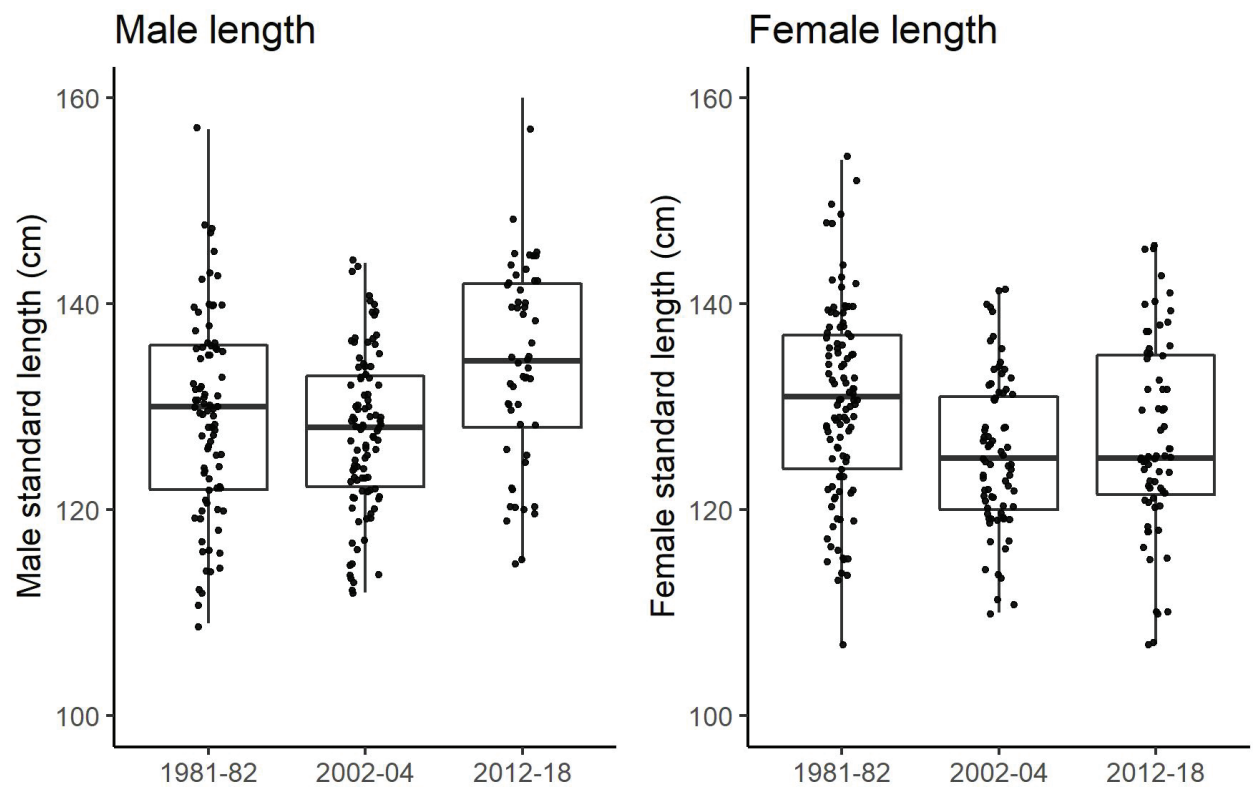

Fig. 5 Standard length of adult male and female ringed seals (eight years of age and older) collected during three time periods (1981-82, 2002-04 and 2012-18) in Svalbard. Linear regression analyses showed that body length of adult animals (8+ years of age) over the three collection periods differed somewhat for both males $\left(F_{(2,234)}=10.7, p<0.05\right)$ and females $\left(F_{(2,245)}=7.9, p<0.05\right.$. While males were slightly longer in the most recent sample compared with both the earlier periods, females were slightly longer in the oldest sample relative to the most recent data.

changes to the marine system in Svalbard fjords, including an "Atlantification" of the fish and invertebrate communities and dramatic declines in sea ice, ringed seals seem to have been able to accommodate the changes, such that their demographic parameters have remained largely unchanged.

The youngest age classes of ringed seals are typically most numerous in hunts, as is the case generally 
for phocid seals (McLaren 1958; Smith 1973, 1987; Chambellant et al. 2012). This is due to the fact that naïve animals are easier to harvest because they are less wary, and young animals are proportionally more numerous (Smith 1973, 1987; Reeves 1998). Furthermore, young seals feed in shallower waters closer to shore, where hunting typically takes place during the open-water season, and therefore, are more easily taken by hunters. The expectation, in this study, was that few young animals would be available for harvest in the 2012-18 sample, as opportunistic field observations (authors and Jon Aars, pers. com.) suggested, reproduction was believed to be negligible in recent years along the west coast of Spitsbergen, Svalbard. The most recent data set cannot be directly compared with the two previous ones for which animals were collected during the spring and young animals seen with their mothers were avoided.

Table 3 Model estimates with Cls for linear regression analyses of ringed seal length for three sampling periods (1981-82, 2002-04, 2012-18), showing between-period differences in length for both sexes.

\begin{tabular}{lcc}
\hline Between periods & $\begin{array}{c}\text { Male length } \\
\text { difference }(\mathrm{cm}) \text { with } \mathrm{Cl}\end{array}$ & $\begin{array}{c}\text { Female length } \\
\text { difference }(\mathrm{cm}) \text { with } \mathrm{Cl}\end{array}$ \\
\hline $1981-82$ vs. 2002-04 & $-1.7(-4.3,1.0)$ & $-5.0(-7.6,-2.4)^{\mathrm{a}}$ \\
$1981-82$ vs. 2012-18 & $5.3(2.2,8.4)^{\mathrm{a}}$ & $-3.6(-6.3,-0.9)^{\mathrm{a}}$ \\
$2002-04$ vs. 2012-18 & $6.9(4.0,9.9)^{\mathrm{a}}$ & $1.4(-1.50,4.3)$ \\
\hline
\end{tabular}

${ }^{a}$ Statistically significant difference at the $p=0.05$ level.
Nevertheless, in the 2012-18 harvest, there was a higher proportion of individuals three years of age or younger than in the earlier periods.

The way the harvest and scientific sampling has been conducted has certainly affected the age distribution of the various sampling periods. Most of the hunting during the periods 1981-82 and 2002-04 was conducted on land-fast ice in fjords along the west coast of Spitsbergen in the early spring. During this time, some females were still accompanied by their pups, and these individuals were avoided, inducing a bias (low number of pups in the samples). Krafft et al. (2007) showed that juvenile seals were pushed towards the outer parts of the fjords, and as hunting was often conducted on the most stable ice deep inside the fjords late in the spring season, the younger age classes would be under-represented (McLaren 1958; Smith 1973; Lydersen \& Gjertz 1987). In the 2012-18

Table 4 Model estimates with Cls for linear regression analyses of ringed seal C-index for three sampling periods (1981-82, 2002-04, 2012-18), showing between-period differences in C-index for both sexes.

\begin{tabular}{llr}
\hline Between periods & $\begin{array}{c}\text { Male C-index } \\
\text { difference with Cl }\end{array}$ & \multicolumn{1}{c}{$\begin{array}{c}\text { Female C-index } \\
\text { difference with Cl }\end{array}$} \\
\hline 1981-82 vs. 2002-04 & $3.75(2.43,5.07)^{\mathrm{a}}$ & $0.98(-0.89,2.87)$ \\
$1981-82$ vs. 2012-18 & $1.11(-1.06,3.29)$ & $-0.69(-3.66,2.28)$ \\
2002-04 vs. 2012-18 & $-2.64(-4.76,-0.52)^{\mathrm{a}}$ & $-1.68(-4.74,1.39)$ \\
\hline
\end{tabular}

astatistically significant difference at the $p=0.05$ level.
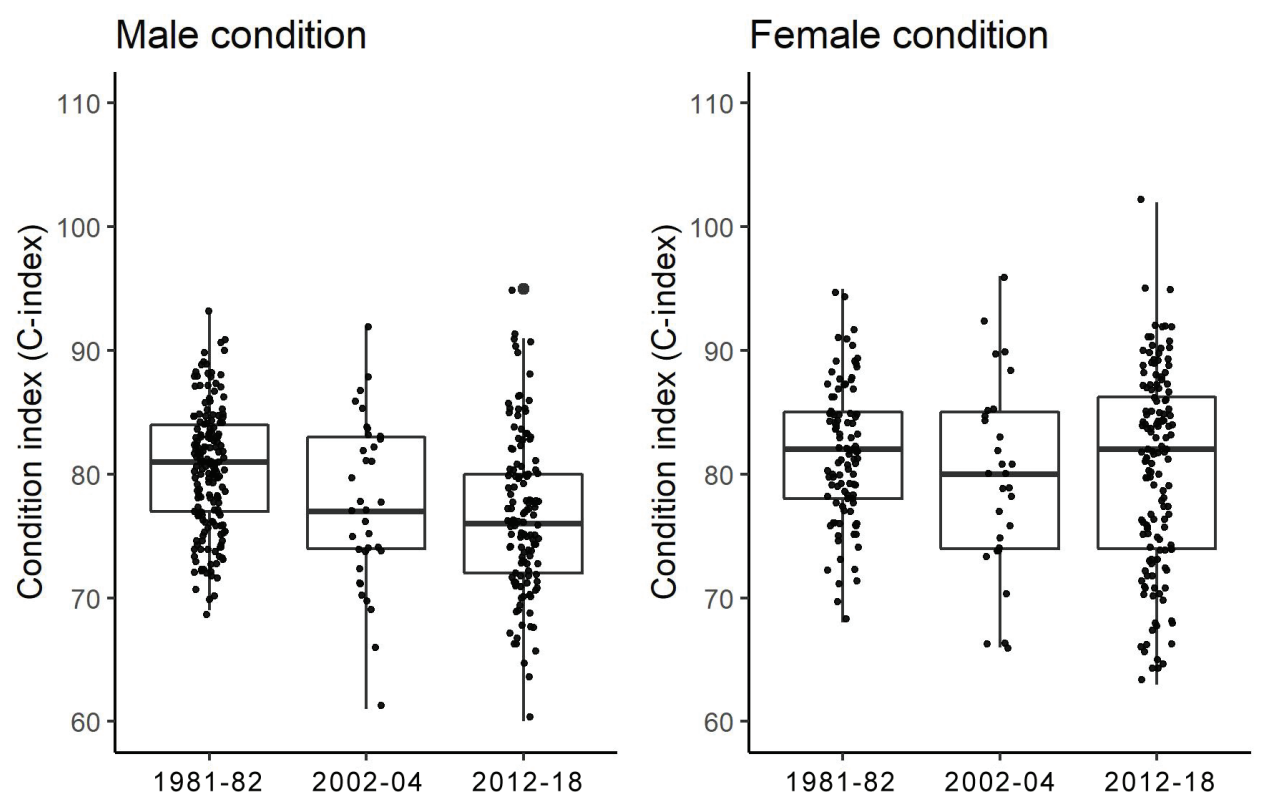

Fig. 6 A comparison of estimated body condition of male and female ringed seals harvested in Svalbard during the three time periods (1981-82, 2002-04 and 2012-18). Linear regression analysis showed that males in 2004-05 had higher C-index values compared with 1981-82 and 2012-18 $\left(F_{(2,33)}=16.04\right.$, $p<0.05)$, while for females there were no effects of sampling period on the $\mathrm{C}$-index $\left(F_{(2,273)}=0.8, p=0.44\right)$. 


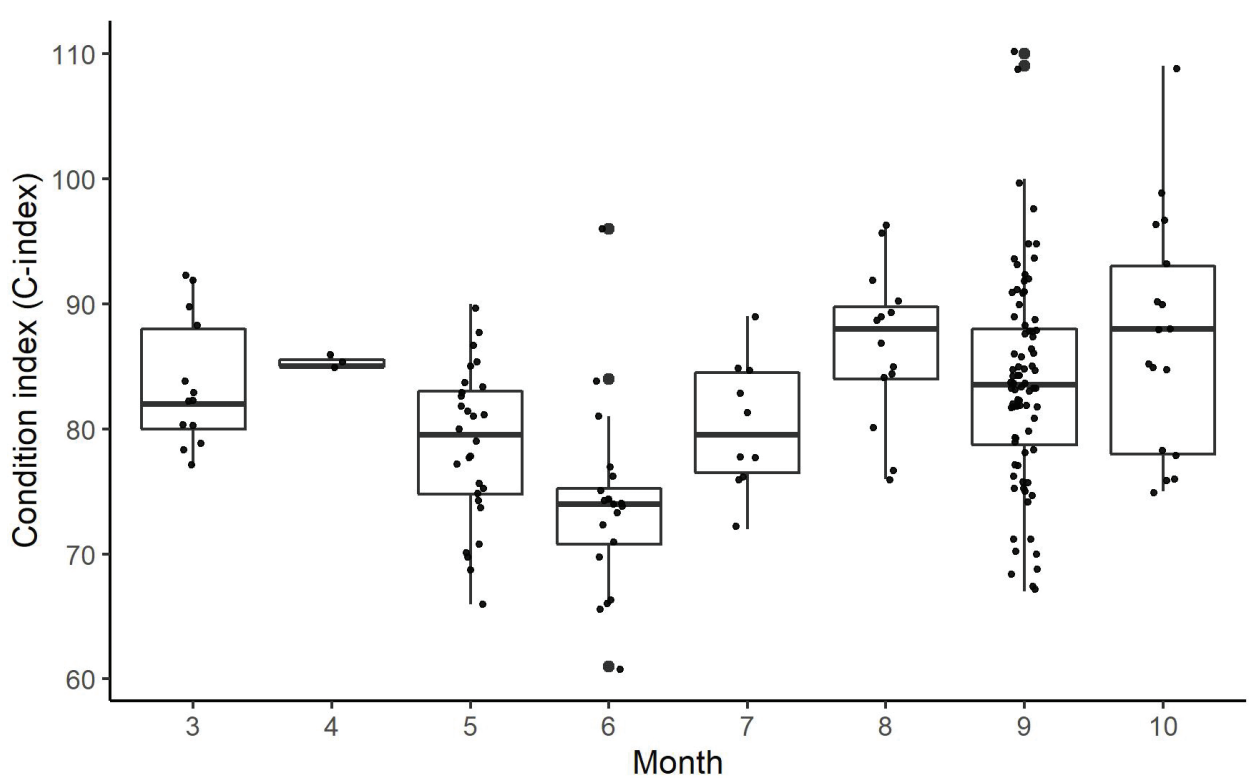

Fig. 7 Seasonal pattern in body condition (males and females combined) for ringed seals in Svalbard, 2012-18. Linear regression analysis showed significant differences in condition seasonally $\left(F_{(7,177)}=6.9, p<0.05\right)$, with $C$-index values being lowest in June and highest in the autumn (August-October).

period, most hunting took place during the open water season, and capture probability would be more equal between different age groups, thereby naturally leading to more young animals in the harvest (McLaren 1958; Smith 1973; Lydersen \& Gjertz 1987). The proportion of young animals in harvest samples has frequently been used as a measure of reproductive success in ringed seals, and large spatial and temporal variations have been reported in previous studies. Some of the variance has been attributed to actual variation in population demographical processes, but sampling biases have also been noted as challenges for interpreting the data (Smith 1973, 1987; Kingsley \& Byers 1998; Teilmann \& Kapel 1998; Chambellant et al. 2012). The number of young animals in Svalbard currently is low compared with some studies that report 30-40\% young-of-the-year pups in the harvest, but higher than others who report fewer than 5\% young-of-the-year pups (McLaren 1958; Smith 1973, 1987; Stirling \& Lunn 1997; Chambellant et al. 2012). Although no scientific data have been collected on survivorship for ringed seals in Svalbard, opportunistic observations during spring research activities in the polar bear and sea-ice programmes suggest very high mortalities of ringed seal pups in recent springs (Jon Aars, pers. com.). Additionally, the seals that have been visible on the spring sea ice have been concentrated in the small areas of available sea ice, and little snow cover on the ice, because of the short ice season, has left ringed seal pups very much exposed to predators (Jon Aars, pers. com.; Lydersen $\delta$
Smith 1989). Stirling (2005) found young-of-the-year ringed seals in low proportions in Hudson Bay in the 1990s and suggested this was due to a long-term shift in reproduction caused by changes in the sea-ice system in that region. For the same population and time period, Ferguson et al. (2005) confirmed that low snow depth was the main driver for reducing the ringed seal recruitment, and early break-up of sea ice in spring also had negative effects.

Reimer et al. (2019) coupled a demographic model to emerging environmental stressors for ringed seals in the Amundsen Gulf and Prince Albert Sound, Canada, and their projections up to year 2100 suggested declines of population size from 50 to $99 \%$. The main driver of the declines was lower proportions of juveniles compared with adults in the studied population. Young animals ( $0-3$ years of age) in the 2012-18 Svalbard sample accounted for $25 \%$ of the population, which is at the low end of the normal range for ringed seals (Smith 1973, 1987; Kingsley \& Byers 1998; Teilmann \& Kapel 1998; Chambellant et al. 2012). Our initial hypothesis was that little reproduction was taking place in the study area, but clearly some recruitment is occurring. One of the explanations might be that young animals are moving onto the west coast from the east, where sea-ice conditions remain better. Alternatively, there might be local production in the area where hunting has taken place, in the sill fjords that occur on the north side of Isfjorden, which retain ice for much longer periods in the spring than most west coast fjord systems, creating a 
spatially limited, but successful habitat for ringed seal reproduction.

Phocid seals usually reach sexual maturity when they have grown to ca. 80-90\% of their final body size (Laws 1956). Thus, there is some flexibility in the age when they are first able to reproduce depending on how fast they grow, which, in turn, depends mainly on food availability. Krafft, Kovacs, Ergon et al. (2006) found that the age of first maturity for ringed seals in Svalbard dropped between the 1980s and the early part of this century, reaching a minimum for this species at 3.8 years of age in the early 2000s. They suggested that this was either due to fewer seals competing for food or greater availability of prey resources for this population. Given the small hunt in Svalbard and the good ice conditions (i.e., good breeding habitat conditions) prior to the scientific harvest in 2002-04, the drop in age at sexual maturity was likely due to abundant food resources. Seals were in good physical condition; ovulation rates were generally high and comparable with similar studies elsewhere in the Arctic (Ferguson et al. 2005; Stirling 2005). Krafft, Kovacs, Ergon et al. (2006) further suggested that the decrease in age at maturity from 1981-82 (Lydersen \& Gjertz 1986) to 2002-04 data could be a result of the increasing polar bear population putting higher predation pressure on ringed seals. However, reduced sea ice, in more recent times, might be making it more difficult for polar bears to hunt ringed seals in the late spring and summer, releasing some of the pressure that would otherwise fall on ringed seals from Svalbard's increasing polar bear population (Hamilton et al. 2017). The results of this study show that maturity has not changed in recent decades, refuting our hypothesis that the observed habitat change has had a great impact on this parameter. Reduced predation success by polar bears on ringed seals in summer and fall in low-ice conditions might be affording adult seals some predator relief (Hamilton et al. 2017).

Ringed seal reproductive rates have been studied in many parts of the Arctic, often in harvested populations where large sample sizes are available (e.g., Harwood et al. 2012). Various parameters have been used to assess reproductive outputs, including the proportion of mature females in the population, which are pregnant or lactating or have ovulated (presence of a corpus luteum) (McLaren 1958; Reeves 1998). Rates vary greatly in both space and time, confirming this species' sensitivity to environmental or ecological processes and conditions when it comes to reproduction (Holst et al. 1999; Iacozza $\&$ Ferguson 2014). Values have been reported from 0.45 for the Barrow Strait in the mid-1980s (Hammill 1987) to 0.91 in Svalbard in 1981-82 (Lydersen \& Gjertz 1986). The 0.94 ovulation rate reported in this study during the period 2012-18 is at the high end of the scale for this parameter. While the term "reproductive rate" includes several types of data describing reproductive potential, pregnancy rate is the ideal parameter for assessing recruitment potential. Ringed seals mate in the late spring, but the fertilized egg does not implant in the uterine wall until approximately four months later, making pregnancy difficult to detect before the autumn. While high ovulation rates are often seen in seals, pregnancy rates are often considerably lower. Fifty-two female seals collected during the fall in the 2012-18 time period, in this study, were sexually mature; $71 \%$ of these were pregnant, a value in the middle of the range of rates reported for ringed seals in other regions and time periods in the Arctic (Reeves 1998; Harwood et al. 2000a, b; Ferguson et al. 2017).

Body size versus age in the most recent sample is similar to early periods, suggesting that there have been no dramatic changes in this biological parameter recently in Svalbard. While males were longer in the most recent sample compared with both the earlier samples, females were slightly longer in the oldest sampling period relative to the most recent data. The data herein further suggest that ringed seals from this population are comparable in size with other populations across the Arctic (Holst \& Stirling 2002; Ferguson et al. 2018).

The current population size and trend are unknown for ringed seals in Svalbard. The most recent surveys were conducted in 2002 and 2003, when Krafft, Kovacs, Frie et al. (2006) estimated some 7585 (95\% CI: 6332 $9085)$ ringed seals in 18 fjords along the west and north coasts of Spitsbergen. The only previous estimate was a crude extrapolation based on the estimated pup production. In the study by Smith \& Lydersen (1991), the production of ringed seal pup in the Svalbard area was estimated to be 8000 individuals based on the sea-ice type, distribution and birth lair densities. Using a modelled relationship for pup production versus population size constructed for harp seals (ICES 2004), this would represent a total population of about 40000 individuals. The differences in methodology, as well as areas covered in the estimates, make these two studies incomparable in terms of trend assessment.

Little is known regarding site fidelity levels in ringed seals, although adult animals are primarily year-round residents of very small home ranges in Svalbard (Hamilton et al. 2016; Hamilton et al. 2019). Subadult animals from this population undertake long-range movements in summer and sometimes shift from one coast to the other in Svalbard (Freitas, Kovacs, Ims, Fedak et al. 2008; Hamilton et al. 2015, 2016). There could, therefore, be influxes of young animals between areas, with pup production (and survival) on the east coast serving as a 
reservoir, which might be supporting the demographic patterns of this study documented in the western parts of Svalbard. Alternatively, though less likely, local production could be greater than currently thought in the hunted area. There are certainly marked differences from fjord to fjord in Svalbard in the prevalence of different water masses (Atlantic Water versus Arctic Water), water temperature and wind exposure, and hence, in the probability that ice will form in winter and remain stable through the spring. "Sill" or "threshold" fjords tend to be sheltered from influxes of Atlantic Water and are more sheltered from the effects of wave action, and hence, retain sea ice. There are several such fjords in the principle hunting areas for ringed seals in Svalbard, including Van Mijenfjorden (especially the inner Van MijenfjordenRindersbukta area) and in the northern parts of Isfjorden (Billefjorden and Tempelfjorden).

Body condition of ringed seals has not declined recently, contrary to what we had predicted, despite the fact that the Arctic prey that this species depends upon are likely in decline (Fossheim et al. 2015; Skaret et al. 2018). Diet of ringed seals in Svalbard is dominated by polar cod (Boreogadus saida), prickleback (Stichaeidae spp.), species in the sculpin families (Cottidae spp.) and ice-associated amphipods (Gjertz \& Lydersen 1986b; Wathne et al. 2000; Labansen et al. 2007; Labansen et al. 2011; Bengtsson et al. 2020). Atlantic species, such as herring (Clupea harengus), blue whiting (Micromesistius poutassou) and krill (Thysanoessa sp.), appear to be increasing slightly in the diet, but polar cod is still dominant (Bengtsson et al. 2020). Lowther et al. (2017) suggested that a dietary shift might have taken place over the last few decades based on stable isotope analyses, but the changes observed could represent changes in the diet of prey species. Some female ringed seals, in particular, harvested in the late summer and early fall, in the current study, had extremely high C-indexes. The reason might be that loss of pups early in the nursing period leads to a significantly lower energetic expenditure on lactation (Lydersen \& Kovacs 1999). Adult females repeatedly failing to go through the full nursing period will result in them retaining their blubber layer thickness. Harvest material from a population with a large number of such females may indicate that the population is doing well, while the truth may be the opposite, as the survival rates of pups are low. A seasonal increase in condition from the spring until the fall was observed in the 2012-18 data, as expected and previously described (Smith \& Hammill 1981; Ryg, Lydersen et al. 1990; Ryg, Smith et al. 1990; Young \& Ferguson 2013; Bengtsson et al. 2020).

In conclusion, demographic data spanning almost four decades suggest that ringed seals in Svalbard have relatively stable body growth rates and good body condition (and hence are finding sufficient prey). However, the production, or survival, of young animals is somewhat low, as proportions of juvenile-age classes are not as high as would be expected in a stable population. Additionally, pregnancy rates are at the low end of the range for this species. Low pup survival is not unexpected, given that there has been a period from 2006 until the present with a markedly reduced ice cover in west coast fjords. Even in years when the ice extent is quite large in this period, the ice has started to form later than normal, and hence, has insufficient snow depth for optimal ringed seal breeding conditions. However, although ringed seals in Svalbard have experienced significant changes in their habitat over the last 30 years, demographic parameters appear to be largely unaffected. Life-history plasticity, in combination with a small-scale regional variation in conditions, might explain the lack of clear patterns of change in demography over time. Monitoring the ringed seals in Svalbard should be continued to gain further insights into possible changes in age structure, body condition and life-history parameters during this time of marked environmental changes. These analyses should be supplemented by additional monitoring to study potential dietary shifts and regional patterns of change within different fjords in Svalbard. The pronounced contrast in the rate of environmental changes in west coast versus east coast fjords could provide considerable insights into responses of ringed seals to climate change and the overall status of this species in Svalbard. Although logistically challenging, more comprehensive monitoring of this species is required to understand the effects of climate change on this population of ringed seals.

\section{Acknowledgements}

The authors thank the Environmental Specimen Bank of Norway (https://miljoprovebanken.no/english), which has supported the collection of samples since 2015 .

\section{Funding}

The Svalbard Environmental Protection Fund provided financial support in 2012 for a pilot project to collect biological samples from sport hunters and trappers and later supported harvest sampling (and aging) for the 2013 and 2014 hunting seasons.

\section{Disclosure statement}

The authors report no conflict of interest. 


\section{References}

Bengtsson O., Lydersen C., Kovacs K.M. \& Lindström U. 2020. Ringed seal (Pusa hispida) diet on the west coast of Spitsbergen, Svalbard, Norway: during a time of ecosystem change. Polar Biology 43, 773-788, doi: 10.1007/ s00300-020-02684-5.

Buchholz F., Werner T. \& Buchholz C. 2012. First observation of krill spawning in the High Arctic Kongsfjorden, west Spitsbergen. Polar Biology 35, 1273-1279, doi: 10.1007/ s00300-012-1186-3.

CAFF 2013. Arctic biodiversity assessment. Status and trends in Arctic biodiversity. Akureyri: Conservation of Arctic Flora and Fauna.

Carlens H., Lydersen C., Krafft B.A. \& Kovacs K.M. 2006. Spring haul-out behavior of ringed seals (Pusa hispida) in Kongsfjorden, Svalbard. Marine Mammal Science 22, 379-393, doi: 10.1111/j.1748-7692.2006.00034.x.

Chambellant M., Stirling I., Gough W.A. \& Ferguson S.H. 2012. Temporal variations in Hudson Bay ringed seal (Phoca hispida) life-history parameters in relation to environment. Journal of Mammalogy 93, 267-281, doi: 10.1644/10-MAMM-A-253.1.

Committee on Marine Mammals 1967. Standard measurements of seals. Journal of Mammalogy 48, 459-462, doi: $10.2307 / 1377778$.

Eriksen E. \& Dalpadado P. 2011. Long-term changes in krill biomass and distribution in the Barents Sea: are the changes mainly related to capelin stock size and temperature conditions? Polar Biology 34, 1399-1409, doi: 10.1007/ s00300-011-0995-0.

Eriksen E., Skjoldal H.R., Gjøsæter H. \& Primicerio R. 2017. Spatial and temporal changes in the Barents Sea pelagic compartment during the recent warming. Progress in Oceanography 151, 206-226, doi: 10.1016/j.pocean. 2016.12.009.

Ferguson S.H., Stirling I. \& McLoughlin P. 2005. Climate change and ringed seal (Phoca hispida) recruitment in western Hudson Bay. Marine Mammal Science 21, 121-135, doi: $10.1111 / j .1748-7692.2005 . t b 01212 . x$.

Ferguson S.H., Young B.G., Yurkowski D.J., Anderson R., Willing C. \& Nielsen O. 2017. Demographic, ecological and physiological responses of ringed seals to an abrupt decline in sea ice availability. PeerJ 5, e2957, doi: 10.7717/ peerj.2957.

Ferguson S.H., Zhu X., Young B.G., Yurkowski D.J., Thiemann G.W., Fisk A.T. \& Muir D.C.G. 2018. Geographic variation in ringed seal (Pusa hispida) growth rate and body size. Canadian Journal of Zoology 96, 649-659, doi: 10.1139/ cjz-2017-0213.

Finley K.J., Miller G.W., Davi R.A. \& Koski W.R. 1983. A distinctive large breeding population of ringed seals (Phoca hispida) inhabiting the Baffin Bay pack ice. Arctic 36, 162-173, doi: 10.14430/arctic2259.

Forland E.J., Benstad R., Hanssen-Bauer I., Haugen J.E. \& Skaugen T.E. 2011. Temperature and precipitation development at Svalbard 1900-2100. Advances in Meteorology 2011, article no. 893790, doi: 10.1155/2011/ 893790.
Fossheim M., Primicerio R., Johannesen E., Ingvaldsen R.B., Aschan M. \& Dolgov V. 2015. Recent warming leads to a rapid borealization of fish communities in the Arctic. Nature Climate Change 5, 673-677, doi: 10.1038/nclimate2647.

Freitas C., Kovacs K.M., Ims R.A., Fedak M.A. \& Lydersen C. 2008. Ringed seal post-moulting movement tactics and habitat selection. Oecologia 155, 193-204, doi: 10.1007/ s00442-007-0894-9.

Freitas C., Kovacs K.M., Ims R.A. \& Lydersen C. 2008. Predicting habitat use by ringed seals (Phoca hispida) in a warming Arctic. Ecological Modelling 217, 19-32, doi: 10.1016/j.ecolmodel.2008.05.014.

Gilg O., Kovacs K.M., Aars J., Fort J., Gauthier G., Gramillet D., Ims R.A., Meltofte H., Moreau J., Pos E., Schmidt N.M., Yannic G. \& Bollache L. 2012. Climate change and the ecology and evolution of Arctic vertebrates. Annals of the New York Academy of Sciences 1249, 166-190, doi: 10.1016/j. ecolmodel.2008.05.014.

Gill M.J., Crane K., Hindrum R., Arneberg P., Bysveen I., Denisenko N.V., Gofman V., Grant-Friedman A., Gudmundsson G., Hopcroft R.R., Iken K., Labansen A., Liubina O.S., Melnikov I.A., Moore S.E., Reist J.D., Sirenko B.I., Stow J., Ugarte F., Vongraven D. \& Watkins J. 2011. Arctic Marine Biodiversity Monitoring Plan (CBMP-MARINE PLAN). CAFF Monitoring Series Report 3. Akureyri: Conservation of Arctic Flora and Fauna.

Gjertz I. \& Lydersen C. 1986a. Polar bear predation on ringed seals in the fast-ice of Hornsund, Svalbard. Polar Research 4 65-68, doi: 10.3402/polar.v4il.6921.

Gjertz I. \& Lydersen C. 1986b. The ringed seal (Phoca hispida) spring diet in northwestern Spitsbergen, Svalbard. Polar Research 4, 53-56, doi: 10.1111/j.1751-8369.1986.tb00518.x.

Hamilton C.D., Kovacs K.M., Ims R.A., Aars J. \& Lydersen C. 2017. An Arctic predator-prey system in flux: climate change impacts on coastal space use by polar bears and ringed seals. Journal of Animal Ecology 86, 1054-1064, doi: 10.1111/1365-2656.12685.

Hamilton C.D., Kovacs K.M. \& Lydersen C. 2019. Sympatric use of a glacial fjord by two Arctic endemic seals. Marine Ecology Progress Series 615, 205-220, doi: 10.3354/meps12917.

Hamilton C.D., Lydersen C., Ims R.A. \& Kovacs K.M. 2015. Predictions replaced by facts: a keystone species' behavioural responses to declining Arctic sea-ice. Biology Letters 11, 1-6, doi: 10.1098/rsbl.2015.0803.

Hamilton C.D., Lydersen C., Ims R.A. \& Kovacs K.M. 2016. Coastal habitat use by ringed seals Pusa hispida following a regional sea-ice collapse: importance of glacial refugia in a changing Arctic. Marine Ecology Progress Series 545, 261-277, doi: 10.3354/meps11598.

Hammill M.O. 1987. Ecology of ringed seal (Phoca hispida Schreber) in the fast-ice of Barrow Strait, Northwest Territories. $\mathrm{PhD}$ thesis, Macdonald College of McGill University, Montreal.

Harwood L.A., Smith T.G. \& Melling H. 2000a. Reproduction and body condition of the ringed seal (Phoca hispida) in the eastern Beaufort Sea, NT, Canada, as assessed through a harvest-based sampling program. Arctic 53, 422-431.

Harwood L.A., Smith T.G. \& Melling H. 2000b. Variation in reproduction and body condition of the ringed seal (Phoca 
hispida) in western Prince Albert Sound, NT, Canada, as assessed through a harvest-based sampling program. Arctic 53, 422-431, doi: 10.14430/arctic872.

Harwood L.A., Smith T.G., Melling H., Alikamik J. \& Kingsley M.C.S. 2012. Ringed seals and sea ice in Canada's western Arctic: harvest-based monitoring 1992-2011. Arctic 65, 377-390, doi: 10.14430/arctic4236.

Holst M., Stirling I. \& Calvert W. 1999. Age structure and reproductive rates of ringed seals (Phoca hispida) on the northwestern coast of Hudson Bay in 1991 and 1992. Marine Mammal Science 15, 1357-1364, doi: 10.1111/ j.1748-7692.1999.tb00898.x.

Holst M. \& Stirling I. 2002. A comparison of ringed seal (Phoca hispida) biology on the east and west sides of the North Water Polynya, Baffin Bay. Aquatic Mammals 28, 221-230, doi: 10.1111/j.1748-7692.2001.tb01304.x.

Iacozza J. \& Ferguson S.H. 2014. Spatio-temporal variability of snow over sea ice in western Hudson Bay, with reference to ringed seal pup survival. Polar Biology 37, 817-832, doi: 10.1007/s00300-014-1484-z.

ICES 2004. Report of the ICES/NAFO Working Group on Harp and Hooded Seals. ICES CM 2004/ACFM: 6. 2-6 September 2003. Arkhangelsk Russia. Copenhagen: International Council for the Exploration of the Seas.

Isaksen K., Nordli O., Forland E.J., Lupikasza E., Eastwood S. \& Niedzwiedz T. 2016. Recent warming on Spitsbergeninfluence of atmospheric circulation and sea ice cover. Journal of Geophysical Research-Atmospheres 121, 11913-11931, doi: 10.1002/2016JD025606.

Kingsley M.C.S. \& Byers T.J. 1998. Failure in reproduction in ringed seals (Phoca hispida) in Amundsen Gulf, Northwest Territories in 1984-1987. In M.P. Heide-Jorgensen \& C. Lydersen (eds.): Ringed seals in the North Atlantic. NAMMCO Scientific Publications 1, 197-210.

Kovacs K.M. 2014. Circumpolar ringed seal (Pusa hispida) monitoring: CAFF's Ringed Seal Monitoring Network. Norwegian Polar Institute Report Series 143. Tromsø: Norwegian Polar Institute.

Kovacs K.M., Aguilar A., Aurioles D., Burkanov V., Campagna C., Gales N., Gelatt T., Goldsworthy S., Goodman S.J., Hofmeyr G.J.G., Härkönen T., Lowry L., Lydersen C., Schipper J., Sipilä T., Southwell C., Stuart S., Thompson D. \& Trillmich F. 2012. Global threats to pinnipeds. Marine Mammal Science 28, 414-536, doi: 10.1111/j.1748-7692.2011.00479.x.

Kovacs K.M. \& Lydersen C. 2008. Climate change impacts on seals and whales in the North Atlantic Arctic and adjacent shelf seas. Science Progress 91, 117-150, doi: 10.3184/003685008X324010.

Kovacs K.M., Lydersen C., Overland J.E. \& Moore S.E. 2011. Impacts of changing sea-ice conditions on Arctic marine mammals. Marine Biodiversity 41, 181-194, doi: 10.1007/ S12526-010-0061-0.

Krafft B.A., Kovacs K.M., Ergon T., Andersen M., Aars J., Haug T. \& Lydersen C. 2006. Abundance of ringed seals (Pusa hispida) in the fjords of Spitsbergen, Svalbard, during the peak molting period. Marine Mammal Science 22, 394-412, doi: 10.1111/j.1748-7692.2006.00035.x.

Krafft B.A., Kovacs K.M., Frie A.K., Haug T. \& Lydersen C. 2006. Growth and population parameters of ringed seals (Pusa hispida) from Svalbard, Norway, 2002-2004. ICES
Journal of Marine Science 63, 1136-1144, doi: 10.1016/j. icesjms.2006.04.001.

Krafft B.A., Kovacs K.M. \& Lydersen C. 2007. Distribution of sex and age groups of ringed seals (Pusa hispida) in the fast-ice breeding habitat of Kongsfjorden, Svalbard. Marine Ecology Progress Series 335, 199-206, doi:10.3354/meps335199.

Labansen A.L, Lydersen C., Haug T. \& Kovacs K.M. 2007. Spring diet of ringed seals (Phoca hispida) from northwestern Spitsbergen, Norway. ICES Journal of Marine Science 64, 1246-1256, doi: 10.1093/icesjms/fsm090.

Labansen A.L., Lydersen C., Levermann N., Haug T. \& Kovacs K.M. 2011. Diet of ringed seals (Pusa hispida) from northeast Greenland. Polar Biology 34, 227-234, doi: 10.1007/ s00300-010-0874-0.

Laidre K.L., Stern H., Kovacs K.M., Lowry L., Moore S.E., Regehr E.V., Ferguson S.H., Wiig Ø., Boveng P., Angliss R.P., Born E.W., Litovka D., Quakenbush L., Lydersen C., Vongraven D. \& Ugarte F. 2015. Arctic marine mammal population status, sea ice habitat loss, and conservation recommendations for the 21 st century. Conservation Biology 29, 724-737, doi: 10.1111/cobi.12474.

Laidre K.L., Stirling I., Lowry L.F., Wiig Ø., Heide-Jørgensen M.P. \& Ferguson S.H. 2008. Quantifying the sensitivity of Arctic marine mammals to climate-induced habitat change. Ecological Applications 18, 97-125, doi: 10.1890/06-0546.1.

Laws R.M. 1956. Growth and sexual maturity in aquatic mammals. Nature 4526, 193-194, doi: 10.1038/178193a0.

Lind S., Ingvaldsen B. \& Furevik T. 2018. Arctic warming hotspot in the northern Barents Sea linked to declining seaice import. Nature Climate Change 8, 634-639, doi: 10.1038/ s41558-018-0205-y.

Lowther A.D., Fisk A., Kovacs K.M. \& Lydersen C. 2017. Interdecadal changes in the marine food web along the west Spitsbergen coast detected in the stable isotope composition of ringed seal (Pusa hispida) whiskers. Polar Biology 40, 2027-2033, doi: 10.1007/s00300-017-2122-3.

Lydersen C. \& Gjertz I. 1986. Studies of the ringed seal (Phoca hispida) in its breeding habitat in Kongsfjorden, Svalbard. Polar Research 4, 57-63, doi: 10.3402/polar.v4il.6920.

Lydersen C. \& Gjertz I. 1987. Population parameters of ringed seals (Phoca hispida) in the Svalbard area. Canadian Journal of Zoology 65, 1021-1027, doi: 10.1139/z87-162.

Lydersen C. \& Hammill M. 1993. Diving in ringed seal (Phoca hispida) pups during the nursing period. Canadian Journal of Zoology 71, 991-996, doi: 10.1139/z93-131.

Lydersen C. \& Kovacs K.M. 1999. Behaviour and energetics of ice-breeding, North Atlantic phocid seals during the lactation period. Marine Ecology Progress Series 187, 265-281, doi: 10.3354/meps 187265 .

Lydersen C. \& Ryg M. 1991. Evaluating breeding habitat and estimating the size of a local population of ringed seal (Phoca hispida) in Svalbard, Norway. Polar Record 27, 223-228, doi: 10.1111/j.1748-7692.2006.00035.x.

Lydersen C. \& Smith T.G. 1989. Avian predation on ringed seal Phoca hispida pups. Polar Biology 9, 489-490, doi: 10.1007/ BF00261031.

McLaren I.A. 1958. The biology of the ringed seal (Phoca hispida Schreher) in the Eastern Canadian Arctic. Fisheries Research Board Canada 118, 1-97, doi: 10.1002/eap.1855. 
McLaren I.A. 1993. Growth in pinnipeds. Biological Reviews 68, 1-79, doi: 10.1111/j.1469-185x.1993.tb00731.x.

McLaren I.A. \& Smith T.G. 1985. Population ecology of seals: retrospective and prospective views. Marine Mammal Science 1, 54-83, doi: 10.1111/j.1748-7692.1985.tb00531.x.

Muckenhuber S., Nilsen F., Korosov A. \& Sandven S. 2016. Sea ice cover in Isfjorden and Hornsund, Svalbard (2000-2014) from remote sensing data. Cryosphere 10, 149-158, doi: 10.5194/tc-10-149-2016.

Notz D. \& Stroeve J. 2016. Observed Arctic sea-ice loss directly follows anthropogenic $\mathrm{CO}_{2}$ emission. Science 354, 747-750, doi: 10.1126/science.aag2345.

Overland J., Hanna E., Hanssen-Bauer I., Kim S.-J., Walsh J.E., Wang M., Bhatt U.S. \& Thoman R.L. 2016. Surface air temperature. Arctic essays. Arctic report card. Accessed on the internet at https://arctic.noaa.gov/Report-Card/ReportCard-2016/ArtMID/5022/ArticleID/27 1/Surface-AirTemperature on 23 February 2021.

Parkinson C.L. 2014. Spatially mapped reductions in the length of the Arctic sea ice season. Geophysical Research Letter 41, 4316-4322, doi: 10.1002/2014GL060434.

R Core Team 2014. R: a language and environment for statistical computing. Vienna: Society for Statistical Computing.

Reeves R.R. 1998. Distribution, abundance and biology of ringed seals (Phoca hispida): an overview. NAMMCO Scientific Publications 1, 9-45, doi: 10.7557/3.2979.

Reimer J.R., Caswell H., Derocher A.E. \& Lewis M.A. 2019. Ringed seal demography in a changing climate. Ecological Applications 29, e01855, doi: 10.1002/eap.1855.

Ryg M., Lydersen C., Markussen N.H., Smith T.G. \& Øritsland N.A. 1990. Estimating the blubber content of phocid seals. Canadian Journal of Fisheries and Aquatic Science 47, 1223-1227, doi: 10.1139/f90-142.

Ryg M., Smith T.G. \& Øritsland N.A. 1990. Seasonal changes in body mass and body composition of ringed seals (Phoca hispida) on Svalbard. Canadian Journal of Zoology 68, 470-475, doi: 10.1139/z90-069.

Ryg M., Smith T.G. \& Øritsland N.A. 1991. Seasonal and developmental changes in reproductive organs of male ringed seals (Phoca hispida) in the Svalbard area. Journal of Zoology 224, 93-100, doi: 10.1111/j.1469-7998.1991.tb04790.x.

Schnute J. 1981. A versatile growth model with statistically stable parameters. Canadian Journal of Fisheries and Aquatic Science 38, 1128-1140, doi: 10.1139/f81-153.

Skaret G., Prozorkevich D., Gjøsæter H. \& Bogstad B. 2018. Influence of ecosystem changes on harvestable resources at high latitudes. Proceedings of the 18th Russian-Norwegian Symposium. Murmansk, 5-7 June 2018. IMR/PINRO Joint Report Series 1. Bergen and Murmansk: Institute of Marine Research and Russian Federal Research Institute of Fisheries and Oceanography.

Smith T.G. 1973. Population dynamics of the ringed seal in the Canadian Eastern Arctic. PhD thesis, McGill University, Montreal.

Smith T.G. 1980. Polar bear predation of ringed and bearded seals in the land-fast sea ice habitat. Canadian Journal of Zoology 58, 2201-2209, doi: 10.1139/z80-302.
Smith T.G. 1987. The ringed seal, Phoca hispida, of the Canadian Western Arctic. Canadian Bulletin of Fisheries and Aquatic Sciences 216. Ottawa: Department of Fisheries and Oceans.

Smith T.G. \& Hammill M.O. 1981. Ecology of the ringed seal, Phoca hispida, in its fast ice breeding habitat. Canadian Journal of Zoology 59, 966-981, doi: 10.1139/z81-135.

Smith T.G., Hammill M.O. \& Taugbol G. 1991. A review of the developmental, behavioral and physiological adaptations of the ringed seal, Phoca hispida, to life in the Arctic winter. Arctic 44, 124-131, doi: 10.14430/arcticl 528.

Smith T.G. \& Lydersen C. 1991. Availability of suitable land-fast ice and predation as factors limiting ringed seal populations, Phoca hispida, in Svalbard. Polar Research 10, 585-594, doi: 10.3402/polar.v10i2.6769.

Smith T.G. \& Stirling I. 1975. The breeding habitat of the ringed seal (Phoca hispida): the birth lair and associated structures. Canadian Journal of Zoology 53, 1297-1305, doi: 10.1139/z75-155.

Stirling I. 2005. Reproductive rates of ringed seals and survival of pups in northwestern Hudson Bay, Canada, 1991-2000. Polar Biology 28, 381-387, doi: 10.1007/s00300-004-0700-7.

Stirling I. \& Lunn N.J. 1997. Environmental fluctuations in Arctic marine ecosystems as reflected by variability in reproduction of polar bears and ringed seals. In S.J. Woodin \& M. Marquiss (eds.): Ecology of Arctic environments. Pp. 167-182. Oxford: Blackwell/British Ecological Society.

Stirling I. \& Smith T.G. 2004. Implications of warm temperatures and an unusual rain event for the survival of ringed seals on the coast of southeastern Baffin Island. Arctic 57, 59-67, doi: 10.14430/arctic483.

Teilmann J. \& Kapel F.O. 1998. Exploitation of ringed seals (Phoca hispida) in Greenland. NAMMCO Scientific Publications 1, 130-151, doi: 10.7557/3.2984.

Vanwormer E., Mazet J.A.K., Hall A., Gi V.A., Boveng P.L., London J.M., Gelatt T., Fadely B., Lander M., Sterling J., Burkanov V., Ream R., Brock P., Rea L., Smith B., Jeffers A., Henstock M., Rehberg M., Burek-Huntington K. \& Goldstein T. 2019. Viral emergence in marine mammals in the North Pacific may be linked to Arctic sea ice reduction. Scientific Reports 9, article no. 15569, doi: 10.1038/ s41598-019-51699-4.

von Bertalanffy L. 1957. Quantitative laws in metabolism and growth. Quarterly Review of Biology 32, 217-231, doi: $10.1086 / 401873$.

Wathne J.A., Haug T. \& Lydersen C. 2000. Prey preferences and niche overlap of ringed seals Phoca hispida and harp seals $P$. groenlandica in the Barents Sea. Marine Ecology Progress Series 194, 233-239, doi: 10.3354/meps 194233.

Wiig Ø., Derocher A.E. \& Belikov S.E. 1999. Ringed seal (Phoca hispida) breeding in the drifting pack ice of the Barents Sea. Marine Mammal Science 15, 595-598, doi: 10.1111/j.1748-7692.1999.tb00828.x.

Young B.G. \& Ferguson S.H. 2013. Seasons of the ringed seal: pelagic open-water hyperphagy, benthic feeding over winter and spring fasting during molt. Wildlife Research 40 , 52-60, doi: 10.1071/WR12168. 